\title{
ANALYSIS OF INSTALLING BALLAST WATER TREATMENT EQUIPMENT ON BULK CARRIERS
}

\author{
Diana Šateikiené $\dot{1}^{1}$ Jolanta Janutènienè $\dot{2}^{2}$, Jonas Čerka ${ }^{3}$ \\ ${ }^{1,3}$ Dept of Ship Engineering, Klaipeda University, Lithuania \\ ${ }^{2}$ Dept of Mechanical Engineering, Klaipeda University, Lithuania
} Submitted 11 January 2015; resubmitted 30 June 2015, 20 September 2015; accepted 13 December 2015;
published online 29 March 2016

\begin{abstract}
In order to protect the world from the invasive species of organisms the cleaning ballast water is required, in other words, discharged water must meet requirements posted by the International Maritime Organization (IMO). The paper provides a comparative analysis of ballast water treatment equipment and its technical parameters. The research has been performed to analyse and assess the effect of the introduced equipment on ship stability, including the effect of its weight, dimensions, performance, price and the efficacy of choice.
\end{abstract}

Keywords: ship; seawater; ballast water treatment; treatment methods; technical characteristics of equipment.

\section{Introduction}

A ballast system of a vessel is one of the most important systems of the ship and is used for improving its marine stability. When ballast water procedures are performed on the ship, millions of various microorganisms are transported together with seawater used for ballast. The microorganisms discharged into water in an alien environment during de-ballasting have a damaging effect on the environment, human health and the ecosystem (Tang et al. 2009; Endresen et al. 2004; Drake, Lodge 2004).

The spread of invasive aquatic species and microorganisms from the ballast water of the ship is one of the most serious problems arising in the present environment of maritime shipping. During a conference held in 2004, the International Maritime Organization (IMO) adopted the BWM Convention Control and Management of Ships Ballast Water and Sediments, which is a prevention measure for the spread of invasive species the adoption of D-1 (Ballast Water Exchange Standard) and D-2 (The Installation of Ballast Water Management Systems on the Ship) standards. The ships carrying on ballasting in the port of one country and de-ballasting in the port of another country are required to follow the D-2 standard of the BWM Convention (Pereira, Brinati 2012; Stehouwer et al. 2013).

A ballast water treatment system that employs active substances must comply with the resolution on the procedure for using these materials adopted by the BWM Convention. The decision on whether there is a possibility of employing active substances is made by the IMO commission. The treatment system cannot pose undue risk to the environment, human health, property or resources (Zhang et al. 2013; Werschkun et al. 2012; Liu et al. 2014; Gollasch et al. 2007; IMO 2011).

The BWM Convention shall come into force after 12 months, when at least 30 IMO Member States, which constitutes $35 \%$ of the world trade shipping tonnage, ratify this convention.

This scientific work is aimed at determining technical parameters of ballast water treatment equipment that may influence the selection of ballast water treatment equipment for a bulk carrier.

The relevant problem (Tamburri et al. 2002; Maranda et al. 2013; Glosten 2011), introduced above, is being solved further in the current paper.

\section{Ballast Water Treatment Technologies}

Each ballast water treatment system differently carries out its cleaning function. Treatment equipment can be installed on a ship, or cleaning can be performed using treatment systems equipped onshore. At present, there are a great number of approved ballast water treatment methods. However, not all techniques are sufficiently effective. Therefore, manufacturers are looking for new solutions to ballast water treatment (RINA Services 2010). 
The main ballast water treatment methods are mechanical, physical and chemical. As for the technologies of ballast water treatment, the total number of systems in the market reaches 70, 28 of which are the type system approved according to IMO and unofficially makes 35 in total.

Ballast water treatment equipment (usually) employs a combination of several methods. The primary treatment method is mechanical: filtering (19 certified methods), hydrocyclone (4 certified methods) etc., and, if necessary, second and third methods can be chemical (ozonation, chlorination, electrolysis, etc.) and physical (UV, deoxidation, etc.). After analysing data based on the information submitted by manufacturers, the distribution of the certified treatment equipment is shown in Fig. 1.

The selection of the treatment system and method depends on the type of a ship, technical parameters, performance indicators and other stages (Table 1) (Lloyd's Register 2015).

Table 1. The procedure for selecting a ballast water treatment system

\begin{tabular}{|l|}
\hline \multicolumn{1}{|c|}{ Initial key aspects } \\
\hline Vessel type and characteristics \\
\hline Trading pattern \\
\hline Ballast capacity and flow rate requirements \\
\hline \multicolumn{1}{|c|}{ Technical and operational considerations } \\
\hline Time required for treatment to be effective \\
\hline Ballast and treatment pumping rates \\
\hline Characteristics of the ballast system \\
\hline Health and safety \\
\hline In-service requirements \\
\hline Explosion proof equipment \\
\hline Power requirements and on-board systems \\
\hline Effects on tank coating and corrosion considerations \\
\hline Controls and alarms \\
\hline Space constraints \\
\hline \multicolumn{1}{|c|}{ Treatment options } \\
\hline Combination filtration and treatment \\
\hline $\begin{array}{l}\text { Chemical options, i.e. chlorination, ozone- } \\
\text { deoxygention and peracetic acid }\end{array}$ \\
\hline Mechanical means, i.e. cavitation \\
\hline UV irradiation \\
\hline Ultrasonic \\
\hline Inclusion in build specifications for new builds \\
\hline Vendor experience of supplying similar systems \\
\hline Equipment approval \\
\hline Commercial considerations \\
\hline
\end{tabular}

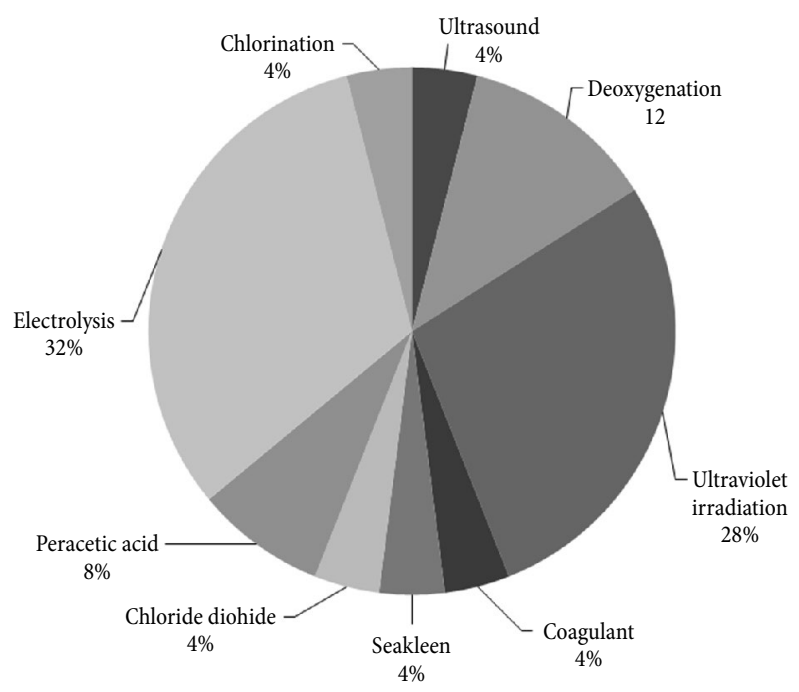

Fig. 1. The use of chemical and physical methods for ballast water treatment

In February 2004, the IMO adopted the International Convention for the Control and Management of Ships Ballast Water and Sediments (the Ballast Water Management or BWM Convention) to regulate discharges of ballast water and reduce the risk of introducing non-native species from the ballast water of ships. To complement the BWM Convention, the IMO adopted over 15 sets of guidelines and other documents contained in its resolutions and circulars of the Marine Environmental Protection Committee (MEPC) (Lloyd's Register 2015).

The BWM Convention will enter into force 12 months after ratification by 30 states thus representing $35 \%$ of the world's merchant shipping tonnage. Once the BWM Convention has entered into force, all ships will be required to manage their ballast water on every voyage by either exchanging or treating it using an approved ballast water treatment system (Lloyd's Register 2015).

The ballast water treatment system must be inexpensive, safe and compact, and the quality of cleaning must comply with the approved IMO standards.

The today's market represents many production companies offering a range of treatment equipment utilizing different methods. The selection of treatment equipment and the method depends on the type of the ship, time required to perform cleaning, weight, cost, operating cost and space for installing equipment onboard. Therefore, vessel owners in continually evolving shipping industry are faced with the problem of selecting the most suitable equipment and methods (Šateikiené, Janutènienè 2012).

The research object of this paper is a bulk carrier vessel (type - Handy) and its main characteristics, which include the overall length $-89.9 \mathrm{~m}$, width $-14.5 \mathrm{~m}$ and the capacity of the ballast water tank $-1676.5 \mathrm{~m}^{3}$.

Research has been performed to analyse and assess the effect of ballast water treatment equipment on the stability of the ship, including the effect of its weight, dimensions, performance, price and the efficacy of choice. 


\section{The Effect of Ballast Water Equipment on the Intact Stability of the Ship}

The size and weight of equipment are significant factors in small vessels. In most cases, a small vessel will have limited space to add equipment and minimal tolerance to a growth in weight an increase in which may have an impact on the payload and stability of the vessel. The approach taken for evaluation in this category is to assign the best score of the system that occupies the smallest footprint and has the lowest weight (Glosten 2011).

The stability of the vessel must be checked before installing the ballast water treatment equipment, because ship designers do not evaluate additional time for designing equipment weight.

Stability is a ship's ability to oppose external forces and return to an equilibrium position after the forces causing inclination stop affecting the ship. The stability of the vessel can be longitudinal and transverse. Longitudinal stability is measured by trim (longitudinal ship inclination) angle $\psi$ and is quite large; thus, there is little or no risk of capsizing the ship forward or aft.

If the centre of ballast water treatment equipment is vertical, when passing through the centre of flotation, a mean change in the draft is (Fig. 2).

$$
\delta d=\frac{P}{\rho \cdot g \cdot S},
$$

where: $d$ - ship draft; $\delta d$ - change in draft; $P$ - weight of equipment; $\rho$ - mass density of outboard seawater; $g$ - the acceleration of gravity; $S$ - waterline area (Molland 2008).

A change in transversal metacentric height after installing ballast water treatment equipment consists of changes in applying the buoyancy centre and gravity centre and a change in the metacentric radius (Table 2).

The initial stability of bulk carrier EVA is described in more detail by the coefficient of transverse stability rather than by metacentric height. This coefficient before loading goods is $\Delta h_{0}$ and after loading is:

$$
(\Delta+P) \cdot\left(h_{0}+\delta h\right)=\Delta h_{0}-P \cdot\left(d+\frac{\delta d}{2}-z_{p}\right),
$$

where: $\Delta$ - displacement; $P$ - weight of equipment; $h_{0}$ metacentric height; $\delta h$ - change in metacentric height; $z_{p}$ - vertical distance from the ship keel to centre of equipment.

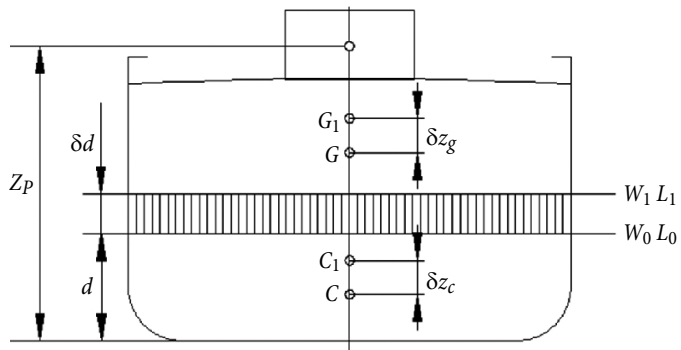

Fig. 2. The average change in the draught, the ship's centre of gravity and the position of the buoyancy centre after installing ballast water treatment equipment
The height at which the ballast water treatment equipment is fitted without affecting metacentric height is equal to:

$$
\left.z_{P}\right|_{\delta h=0}=d+\frac{\delta d}{2}-h_{0} .
$$

A horizontal plane passing at this level is a marginal plane of metacentric height (Fig. 3). If the ballast water treatment equipment is installed below this plane, metacentric height will increase, and if it is above the plane - height will decrease.

Table 2. The assessment of transversal metacentric height

\begin{tabular}{|l|l|}
\hline $\begin{array}{l}\text { Change in transversal } \\
\text { metacentric height }\end{array}$ & $\delta h=\delta z_{c}+\delta r+\delta z_{g}$ \\
\hline $\begin{array}{l}\text { Change in the application } \\
\text { of the buoyancy centre }\end{array}$ & $\delta z_{c}=\frac{P}{\Delta+P} \cdot\left(d+\frac{\delta d}{2}-z_{c}\right)$ \\
\hline $\begin{array}{l}\text { Change in the metacentric } \\
\text { radius }\end{array}$ & $\delta r=-\frac{P}{\Delta+P} \cdot r$ \\
\hline $\begin{array}{l}\text { Change in the applicate of the } \\
\text { ships centre of gravity }\end{array}$ & $\delta z_{g}=-\frac{P}{\Delta+P} \cdot\left(z_{p}-z_{g}\right)$ \\
\hline
\end{tabular}

The coefficient of transverse stability describes the initial stability, because the feature of resisting the inclination of the ship depends on transversal metacentric height and ship's water tank. A change in the size of this coefficient proportionally adjusts variations in ship stability: having installed equipment above critical plane $z_{p}$, the initial stability decreases and vice versa:

$$
\left.z_{p}\right|_{\delta(\Delta h)=0}=d+\frac{\delta d}{2} .
$$

After installing ballast water treatment equipment between both planes, one characteristic of stability $(h)$ improves while the other $(\Delta h)$ - deteriorates (Fig. 3). Ship stability is described in detail by parameter $(\Delta h)$.

The displacement of the vessel varies by additionally installing the ballast water treatment equipment. A change in the coefficient of stability describes the absolute ability of the ship to resist inclination while a change in metacentric height reflects variation in this ability.

Under the requirements of the International Code on Intact Stability, a ship is safe under requirements, which presented in Table 3.

These requirements are raised for the ship intact stability scheme $l_{\theta}=f(\theta)$ (Fig. 4).

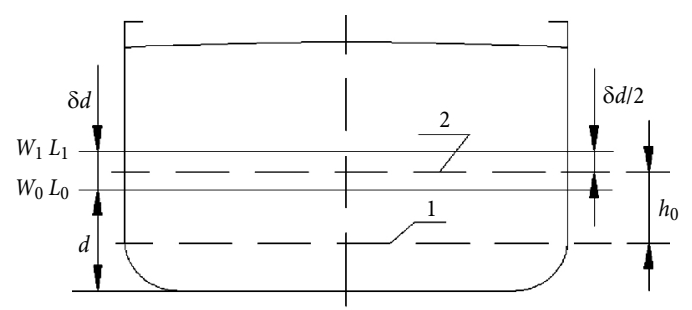

Fig. 3. The marginal plane of metacentric height (1) and the marginal plane of the coefficient of transversal stability (2) 
Table 3. International Code on Intact Stability requirements for ship

\begin{tabular}{|l|c|}
\hline \multicolumn{1}{|c|}{ Limit } & Min/max \\
\hline Area from 0.00 deg to $30.00 \mathrm{deg}$ & $>0.0550 \mathrm{~m}-\mathrm{R}$ \\
\hline Area from 0.00 deg to $40.00 \mathrm{deg}$ or flood & $>0.0900 \mathrm{~m}-\mathrm{R}$ \\
\hline Area from 30.00 deg to $40.00 \mathrm{deg}$ or flood & $>0.0300 \mathrm{~m}-\mathrm{R}$ \\
\hline Righting arm at 30.00 deg or MaxRA & $>0.200 \mathrm{~m}$ \\
\hline Angle from 0.00 deg to MaxRA & $>25.00 \mathrm{deg}$ \\
\hline GM at equilibrium & $>0.150 \mathrm{~m}$ \\
\hline
\end{tabular}

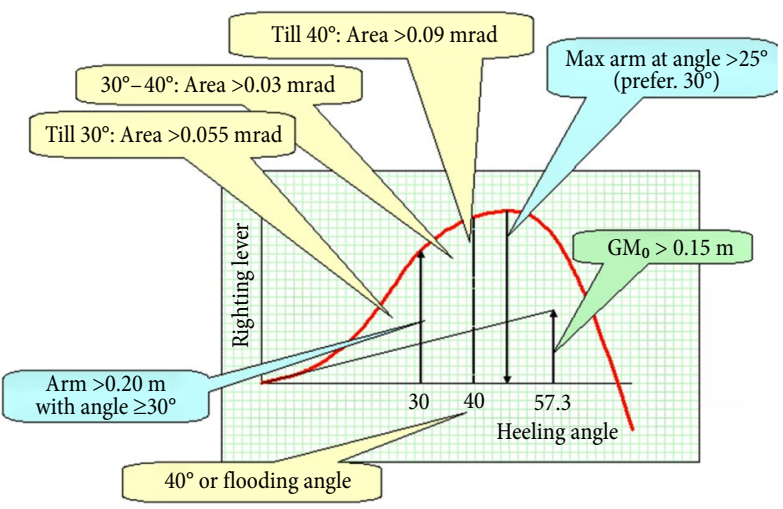

Fig. 4. Minimum IMO requirements for the ship intact stability scheme (International Code on Intact Stability)

The ship righting arm is calculated as:

$$
l_{\theta}=y_{c} \cdot \cos \theta+\left(z_{c}-z_{c 0}\right) \cdot \sin \theta-a \cdot \sin \theta,
$$

where: $l_{\theta}$ - righting arm of the ship; $y_{c}, z_{c}$ - transverse and vertical centre of buoyancy (heel angle $\theta$ ); $z_{c 0}$ - vertical centre of buoyancy (heel angle $\theta \approx 0$ ); $a$ - vertical distance from the centre of buoyancy to the centre of ship gravity; $\theta$ - angle of ship heel.

The numerical values of the shoulders of form stability decrease with an increase in the ship's displacement - when the ship is loaded (or additional equipment is installed), its stability will deteriorate (Fig. 5). The goods loaded below the ship's centre of gravity and the shoulders of ship stability $\delta l_{s y}$ can compensate negative change $\delta l_{f}$ in case only it is very slight.

If a ballast water treatment plant is installed high on the ship, the stability of the vessel will only get worse,

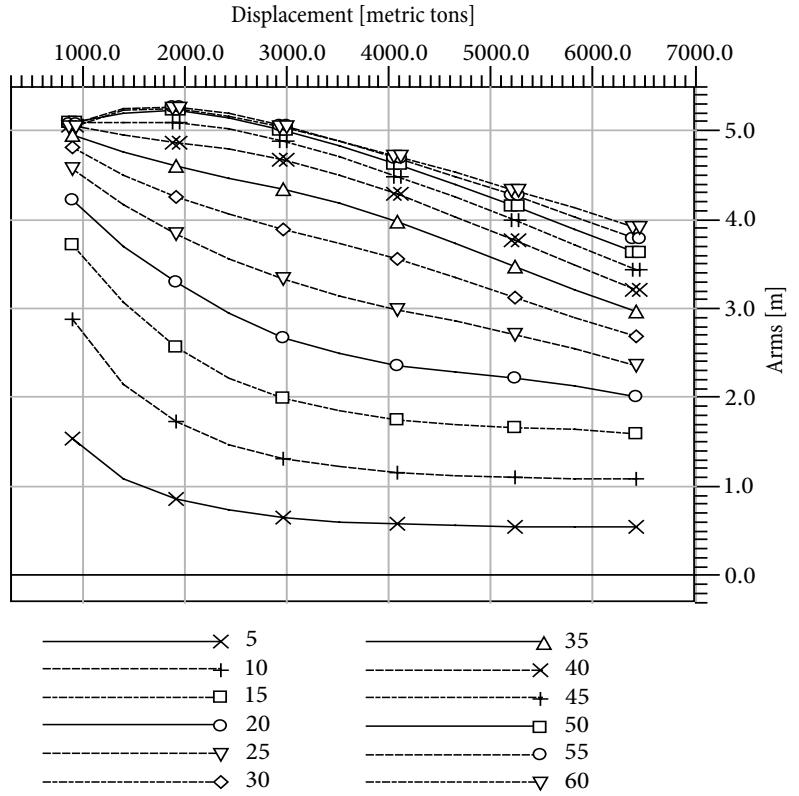

Fig. 5. A decrease in the stability of cross-curves when the displacement increases

and if the stability of the ship is near the allowed limit value before installing equipment, it is likely that this limit will be exceeded when installing equipment in any other location of the ship.

The mathematical experiment with vessel EVA revealed that the set requirements met the values of the following minimum Vertical Centre of Gravity (VCG) (Table 4).

The equipment installed at the highest (deck $7500 \mathrm{~mm}$ ) and lowest places (hold $-1051 \mathrm{~mm}$ ) onboard has been measured. The mass of the equipment to ensure that a change in the ship's centre of gravity would be $0.5 \%$ of the allowable value of the centre of gravity (such precision is required in engineering calculations, then the impact is assessed), which is determined from the derived table, has been chosen (Table 5).

After installing equipment weighing $17.2 \mathrm{t}$ in the hold of bulk carrier EVA and the ship's draught of $3 \mathrm{~m}$, the change in the ship centre of gravity will be $0.036 \mathrm{~m}$, which accounts for $0.5 \%$ of the permissible values of the ship centre of gravity. The selected equipment will have a minimal impact on the stability of the ship; it will be positive, and the stability of the ship will improve.

Table 4. Calculation results and the trim righting arm held at zero

\begin{tabular}{|c|c|c|c|c|c|c|c|c|}
\hline $\begin{array}{c}\text { Intact displacement } \\
{[\mathrm{MT}]}\end{array}$ & $\begin{array}{c}\text { Intact draft at MS } \\
(\mathrm{m})\end{array}$ & $\begin{array}{c}\text { Max VCG } \\
{[\mathrm{m}]}\end{array}$ & $\begin{array}{c}\text { Limit 1 } \\
{[\%]}\end{array}$ & $\begin{array}{c}\text { Limit 2 } \\
{[\%]}\end{array}$ & $\begin{array}{c}\text { Limit 3 } \\
{[\%]}\end{array}$ & $\begin{array}{c}\text { Limit 4 } \\
{[\%]}\end{array}$ & $\begin{array}{c}\text { Limit 5 } \\
{\left[{ }^{\circ}\right]}\end{array}$ & $\begin{array}{c}\text { Limit 6 } \\
{[\%]}\end{array}$ \\
\hline 2953.6 & 3.00 & 7.262 & 30.0 & 12.8 & 0.0 & 32.4 & 2.4 & 89.0 \\
\hline 3501.7 & 3.50 & 6.856 & 8.6 & 14.1 & 43.3 & 58.3 & 5.8 & 0.0 \\
\hline 4064.4 & 4.00 & 6.516 & 4.4 & 9.6 & 37.4 & 52.4 & 5.0 & 0.0 \\
\hline 4639.5 & 4.50 & 6.210 & 12.1 & 1.8 & 0.1 & 24.8 & 2.9 & 64.4 \\
\hline 5223.1 & 5.00 & 5.633 & 93.4 & 66.0 & 43.3 & 58.6 & 0.0 & 370.1 \\
\hline 5813.7 & 5.50 & 4.853 & 220.7 & 180.3 & 152.9 & 142.0 & 0.0 & 851.9 \\
\hline 6409.7 & 6.00 & 4.251 & 291.1 & 241.6 & 207.9 & 180.7 & 0.0 & 1244.4 \\
\hline
\end{tabular}


Table 5. The effect of ballast water treatment equipment on the stability of the ship

\begin{tabular}{|l|c|c|c|c|}
\hline $\begin{array}{c}\text { Location of equipment } \\
\text { installation }\end{array}$ & Draught of the ship [m] & $\begin{array}{c}\text { Weight of the } \\
\text { equipment }[\mathrm{t}]\end{array}$ & $\begin{array}{c}\text { Change in the ship centre } \\
\text { of gravity } \delta z_{g}[\mathrm{~m}]\end{array}$ & Effect on ship stability \\
\hline hold & 3 & 17.2 & -0.036 & positive \\
\hline hold & 6 & 43 & -0.021 & positive \\
\hline deck & 3 & 525 & 0.036 & negative \\
\hline deck & 6 & 43 & 0.021 & negative \\
\hline
\end{tabular}

After increasing the weight of the ballast water treatment equipment to the maximum value of $43 \mathrm{t}$ and the ship's draught to $6 \mathrm{~m}$, the change in the ship centre of gravity will make $0.021 \mathrm{~m}$, which accounts for $0.5 \%$ of the permissible values of the ship centre of gravity. The selected equipment will have a minimal impact on the stability of the ship; it will be positive, and the stability of the ship will improve.

The permissible value of the ship centre of gravity will change by $0.5 \%$ after installing equipment weighing $525 \mathrm{t}$ on the ship deck under the ship's draught of $3 \mathrm{~m}$. The selected equipment will have a minimal impact on the stability of the ship; it will be negative, and the stability of the ship will deteriorate.

The maximum value of the ship centre of gravity will change by $0.5 \%$ after installing equipment weighing $43 \mathrm{t}$ on the deck of the ship and the ship's draught to $3 \mathrm{~m}$. Stability will deteriorate.

The ballast water treatment equipment will be negative due to the stability of the ship depending on the draught of the ship: first, the ship's draught to $3 \mathrm{~m}$ and equipment weighing $43 \mathrm{t}$ in the deck; then the ship's draught to $6 \mathrm{~m}$ and equipment weighing $525 \mathrm{t}$ on the deck.

\section{Dimensions of the Ballast Water Treatment Equipment}

According to Lloyd's Register (http://www.lr.org), the footprint of the systems, as reported by manufacturers, varies between $0.25 \mathrm{~m}^{2}$ and $30 \mathrm{~m}^{2}$ for a $200 \mathrm{~m}^{3} / \mathrm{h}$ unit. As the classification society notes, while units may be predominantly modular, this does not imply that the footprint increases proportionately with flow capacity.

The analysis of the equipment employed by 17 suppliers has showed that when the capacity of ballast water treatment equipment is $200 \mathrm{~m}^{3} / \mathrm{h}$, the equipment occupies an area from 1.6 to $25 \mathrm{~m}^{2}$, and the average value is $5 \mathrm{~m}^{2}$ (Fig. 6). The amount of other manufactured equipment having higher capacity is smaller. 13 systems with the capacity of $2000 \mathrm{~m}^{3} / \mathrm{h}$ occupy an area of 4 to $100 \mathrm{~m}^{2}$, and the average is $25 \mathrm{~m}^{2}$. Commonly, the ballast water treatment equipment is modular, but this does not mean that the area covered by the equipment increases in proportion with its capacity (yield). The height of the analysed ballast water treatment equipment ranged from 1 to $3 \mathrm{~m}$.

The dimensions of the treatment equipment are those of the equipment assembled in operational ships. There are no anticipated places for installing treatment equipment in operational ships and the dimensions are limited by passages and installed equipment while transporting it to the selected place.
The installation of the ballast water treatment equipment on the ship has to take place in the machine section. As for bulk carrier EVA, ballast pumps are also installed in the machine section. Depending on the used ballast water treatment method and its efficiency, equipment dimensions are different. The ballast water treatment equipment can be modular and provided in various configurations, sizes and forms, depending on the available free area. The advantage of the equipment is that it can be assembled as separate units if there is no possibility of installing it all in one place.

The deadweight of bulk carrier EVA is 4300 tons. It has 15 different ballast tanks with a total volume of $1676.5 \mathrm{~m}^{3}$, and system capacity is $250 \mathrm{~m}^{3} / \mathrm{h}$.

For selecting the filtration and UV irradiation modules of the ballast water treatment equipment designed for small and average (1000-10000 deadweight) ships, the treatment capacity of the equipment ranges from 250 to $1250 \mathrm{~m}^{3} / \mathrm{h}$.

The universal capacity of EVA ballast pumps is $Q=$ $500 \mathrm{~m}^{3} / \mathrm{h}$ and the ship has two pumps in the ballast system. Thus, the 'BWT 500i' module equipment of $D=$ $1000 \mathrm{~mm}$ in length, $B=1400 \mathrm{~mm}$ in width (with pipe branch connection) and $H=2400 \mathrm{~mm}$ in height has been selected. The total area occupied by the equipment makes $3.36 \mathrm{~m}^{3}$.

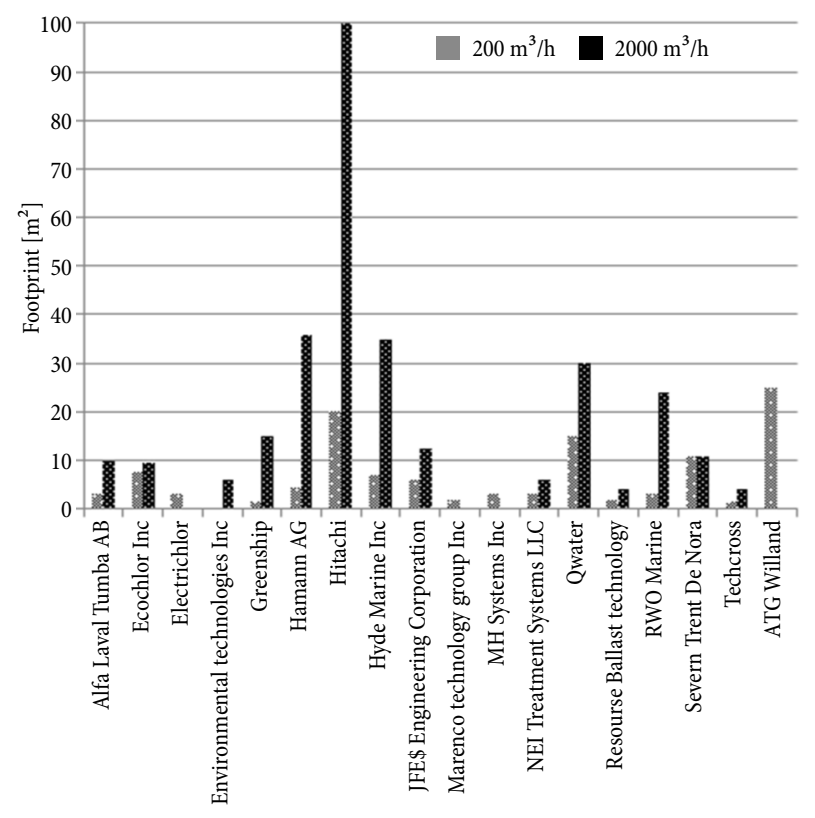

Fig. 6. The distribution of the footprint of ballast water treatment equipment 
The analysis of the possibilities of installing the 'BWT 500i' module treatment system indicates that it is advisable and easy to assemble the equipment in the starboard area near ballast pumps. The height of the premises in the proposed location is $2.73 \mathrm{~m}$, and therefore the equipment is installed between $22-25$ beams.

\section{Capacity of Ballast Water Treatment Equipment}

Each ballast water treatment system is described by its capacity, which indicates how much the ballast water system can process per hour. For selecting the treatment system, this norm has to be sufficient enough to fill the ballast tank of the ship and to utilise the capacity of the used pumps.

Treatment Rated Capacity (TRC) is the maximum level of continuous capacity expressed in cubic meters per hour for which the Ballast Water Management System (BWMS) is the one of the approved type, which indicates the amount of ballast water that can be treated per unit of time established by the BWMS. The standard has been implemented by the D-2 Regulation of Convention. The treatment rated yield has to be sufficient enough to match the ballast capacity of the ship and a typical speed of ballast operations.

Treatment equipment capacity is the maximum amount of the treated ballast water per unit of time. For research on Bulk Carriers, a vessel (type - Handy, representative capacity of ballast water tanks $-1676.5 \mathrm{~m}^{3}$ ) was selected. Therefore, this parameter is important.

Where the ballast system has the capacity exceeding the TRC of an in-line BWMS, an appropriate flow control arrangement is to be provided for ballast pumps.

When a suction system uses centrifugal ballast pumps without the possibility of flow control, the initial yield through the ballast pump can exceed the default yield. The treatment system still has to be able to treat ballast water according to the approval of its type until the yield decreases to the maximum continuous yield.

In such cases, when the yield of the treatment system is indicated for one single ballast pump, a ballast water management plan includes particular instructions stating that it is not allowed to use more than one ballast pump.

The analysis of the manufactured equipment shows that the majority of equipment is designed for approximately $250 \mathrm{~m}^{3} / \mathrm{h}$ yield (Table 6). It is considered that this yield is required for the first stage of ships that have to be equipped with the ballast water treatment technology. Since the systems are modular structures (except for the gas injection type), there are no technical limitations to the maximum yield, except those determined by the size and/or expense. One can also find pre-installed systems. Their yield exceeds $500 \mathrm{~m}^{3} / \mathrm{h}$.

\section{Price for Connecting the Ballast Water Treatment Equipment in Regards to Technical Characteristics}

The main technical parameters of the system related with ballast water treatment are the yield, the total size of the system and expense that includes CApital EXpenditure (CAPEX) and OPerational EXpenditure (OPEX).

Approximate operational costs for $1000 \mathrm{~m}^{3}$ of treated water are shown in the diagram (13 systems) (Fig. 7).

Data analysis of 13 ballast water treatment systems shows that the average estimated operational costs are 10 cents per $1 \mathrm{~m}^{3}$ in US dollars. The operational costs of the majority of the analysed ballast water treatment equipment for $1 \mathrm{~m}^{3}$ of ballast water range from 1 to 35 cents.

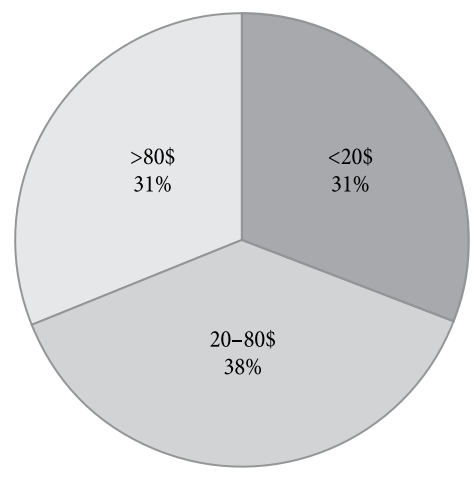

Fig. 7. The distribution of operational costs for ballast water treatment equipment

Table 6 . The total number of ballast water management systems

\begin{tabular}{|c|c|c|c|c|c|c|}
\hline \multirow{2}{*}{ BWMS capacity $\left[\mathrm{m}^{3} / \mathrm{h}\right]$} & \multicolumn{6}{|c|}{ BWMS } \\
\hline & Ozone & Deoxygenation & Oxidation & UV irradiation & Flocculation & Chlorination \\
\hline 250 & 2 & - & 1 & 5 & 1 & 6 \\
\hline 500 & 1 & 1 & 1 & 6 & 1 & 9 \\
\hline 1000 & 1 & 1 & 1 & 6 & 1 & 9 \\
\hline 2000 & 1 & 1 & 1 & 5 & 1 & 8 \\
\hline 3000 & 1 & 1 & 1 & 5 & - & 7 \\
\hline 4000 & 1 & 1 & - & 2 & - & 6 \\
\hline 5000 & 1 & 1 & - & 2 & - & 6 \\
\hline 6000 & 1 & 1 & - & 2 & - & 3 \\
\hline 8000 & 1 & - & - & - & - & 1 \\
\hline 10000 & - & - & - & - & - & 1 \\
\hline
\end{tabular}


Table 7. The dependence of power requirements for ballast water treatment systems on capacity

\begin{tabular}{|c|c|c|c|c|}
\hline \multirow{2}{*}{ Ballast water treatment method } & \multicolumn{2}{|c|}{ Power requirements [kWh] } & \multicolumn{2}{|c|}{ Capacity $\left[\mathrm{m}^{3} / \mathrm{h}\right]$} \\
\hline & $500 \mathrm{~m}^{3}$ system & $5000 \mathrm{~m}^{3}$ system & Min & Max \\
\hline Filtration $+\mathrm{UV}$ irradiation $+\mathrm{TiO}_{2}$ & $34-64$ & $260-500$ & 250 & 3000 \\
\hline Electrolysis/Electrochlorination + Cavitation & $16-22$ & $165-220$ & 200 & 5000 \\
\hline Filtration + UV irradiation & $30-128$ & $171-770$ & 21 & 25000 \\
\hline Filtration + Ozonation + UV irradiation & $45.6-62.4$ & $456-582$ & 75 & 3000 \\
\hline Electrolysis/Electrochlorination $\left(\mathrm{ClO}_{2}\right)$ & $4.2-6.6$ & $11.9-33$ & 250 & 16200 \\
\hline Hydrocyclone + Filtration + Electrolysis/Electrochlorination & $15-20$ & - & 50 & 3000 \\
\hline $\begin{array}{l}\text { Filtration + Electrolysis/Electrochlorination + Ultrasonic } \\
\text { treatment + Hydroxyl radical }\end{array}$ & 8.5 & 85 & 50 & 9000 \\
\hline $\begin{array}{l}\text { Filtration + Electrolysis/Electrochlorination + Residual } \\
\text { chemical reduction) }\end{array}$ & $13-30$ & $76-330$ & 75 & 8000 \\
\hline Filtration + Chlorination $(\mathrm{NaClO})+$ Residual (chemical reduction) & 6.2 & 13.4 & 200 & 4500 \\
\hline Filtration + Chlorination $\left(\mathrm{Cl}_{2}\right.$ chlorine $)$ & 2.1 & - & 250 & 1500 \\
\hline Filtration + Electrolysis/Electrochlorination & $17-48.4$ & $175-568$ & 100 & 7200 \\
\hline
\end{tabular}

The analysis of their operational costs indicates that the costs do not directly depend on the ballast water treatment method (Table 7). In most cases (UV irradiation, electrolysis or ozonation), the costs directly depend on the power of the equipment, except for ballast water treatment equipment that has a gas injection mechanism or chemical storage.

Operational costs depend on power requirements for the ballast water treatment equipment. The analysis of requirements for their power indicates that power requirements do not directly depend on the capacity of ballast water treatment equipment.

Many suppliers keep CAPEX as confidential information. CAPEX on 11 ballast water treatment systems analysed using the capacity of $200 \mathrm{~m}^{3} / \mathrm{h}$ ranges from $\$ 135000$ to $\$ 650000$ each, and the average value is $\$ 340000$ (Fig. 8). The value of 8 systems having the

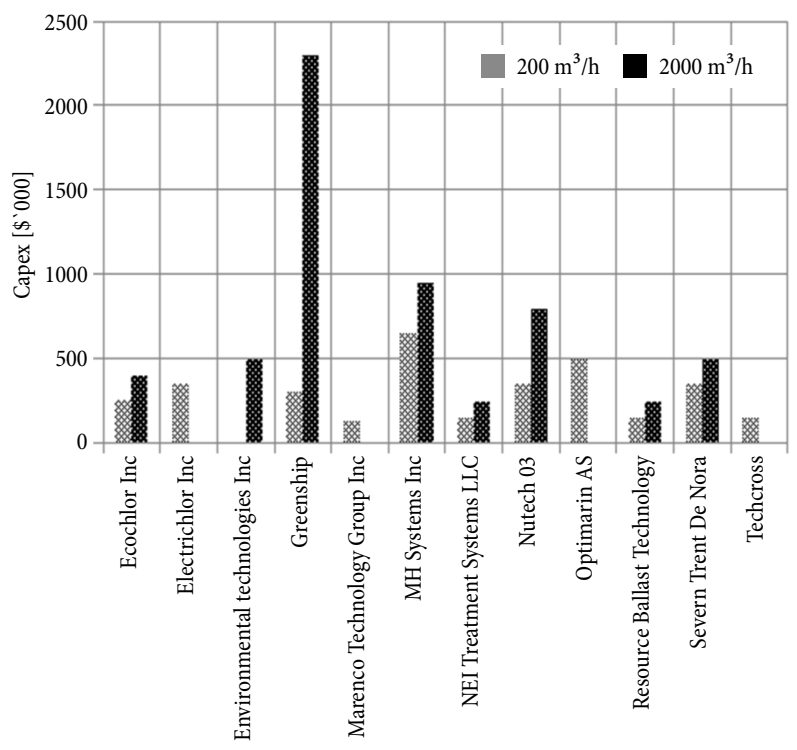

Fig. 8. The distribution of CAPEX on the ballast water treatment equipment capacity of $2000 \mathrm{~m}^{3} / \mathrm{h}$ is $\$ 250000$ to $\$ 2300000$ each, and the average value is $\$ 800000$.

The analysis of CAPEX on the ballast water treatment equipment indicates that there is no direct dependence between the price of the equipment and the ballast water treatment method.

\section{Conclusions}

If ballast water treatment equipment is installed in small ships that have not been designed or built for it, it can influence the ships' stability. The application of mathematical modelling to bulk carrier EVA has disclosed that ship's stability would become worse if the weight of the ballast water treatment equipment was 42 tons and installed shipboard.

The ballast water treatment system installed in the ship can occupy an area of 1.6 to $100 \mathrm{~m}^{2}$ depending on its capacity. Height ranges from 1 to 3 meters. The components of treatment equipment can be arranged separately if there is no place for the entire system. It is advisable and easy to assemble the treatment equipment in the starboard area of bulk carrier EVA near ballast pumps. The height of the premises in the proposed location is $2.73 \mathrm{~m}$.

The capacity of ballast water treatment equipment ranges from 250 to $10000 \mathrm{~m}^{3} / \mathrm{h}$, mostly from 250 to $2000 \mathrm{~m}^{3} / \mathrm{h}$. EVA requires ballast water treatment equipment with the capacity of $1300 \mathrm{~m}^{3} / \mathrm{h}$. The analysis of the capacity of the ballast water treatment equipment shows that, according to the capacity of the equipment, chlorination is available in the widest range.

The selection of the ballast water treatment equipment is defined by operational and CAPEX. The average operational cost of the analysed equipment is 10 cents per $1 \mathrm{~m}^{3}$ in US dollars. Expenses do not directly depend on the treatment method. The main factor influencing operational costs is equipment capacity. CAPEX varies from $\$ 135000$ to $\$ 2300000$ and directly depends on equipment capacity. 


\section{Acknowledgements}

This work resulted from the Taiwan-Latvia-Lithuania Cooperation Project BALMAN 'Development of the ships' ballast water management system to reduce biological invasions', project \# TAPLLT-14-013 (for JJ and DS).

\section{References}

Drake, J. M.; Lodge, D. M. 2004. Global hot spots of biological invasions: evaluating options for ballast-water management, Proceedings of the Royal Society B: Biological Sciences 271(1539): 575-580. http://dx.doi.org/10.1098/rspb.2003.2629

Endresen, Ø.; Behrens, H. L.; Brynestad, S.; Andersen, A. B.; Skjong, R. 2004. Challenges in global ballast water management, Marine Pollution Bulletin 48(7-8): 615-623. http://dx.doi.org/10.1016/j.marpolbul.2004.01.016

Glosten. 2011. Ballast Water Treatment System Evaluation for Small Vessels. Prepared for Isle Royale National Park, Houghton, MI. The Glosten Associates, Consulting Engineers Serving the Marine Community, US. 54 p.

Gollasch, S.; David, M.; Voigt, M.; Dragsund, E.; Hewitt, C.; Fukuyo, Y. 2007. Critical review of the IMO international convention on the management of ships' ballast water and sediments, Harmful Algae 6(4): 585-600. http://dx.doi.org/10.1016/j.hal.2006.12.009

IMO. 2008. International Code on Intact Stability. International Maritime Organization (IMO).

Liu, T.-K.; Chang, C.-H; Chou, M.-L. 2014. Management strategies to prevent the introduction of non-indigenous aquatic species in response to the ballast water convention in Taiwan, Marine Policy 44: 187-195. http://dx.doi.org/10.1016/j.marpol.2013.08.023

Lloyd's Register. 2015. Understanding Ballast Water Management: Guidance for Shipowners and Operators. UK. 28 p.

Maranda, L.; Cox, A. M.; Campbell, R. G.; Smith, D. C. 2013. Chlorine dioxide as a treatment for ballast water to control invasive species: Shipboard testing, Marine Pollution Bulletin 75(1-2): 76-89. http://dx.doi.org/10.1016/j.marpolbul.2013.08.002

Molland, A. F. 2008. The Maritime Engineering Reference Book: a Guide to Ship Design, Construction and Operation. Butterworth-Heinemann. 920 p.

Pereira, N. N.; Brinati, H. L. 2012. Onshore ballast water treatment: a viable option for major ports, Marine Pollution Bulletin 64(11): 2296-2304. http://dx.doi.org/10.1016/j.marpolbul.2012.07.026

RINA Services. 2010. Ballast Water Convention and Ballast Water Treatment Systems: Guidance on Procurement, Installation, Operation and Certification. Technical Report. RINA Services S.p.A. Genova. Italy. 52 p.

Stehouwer, P. P.; Van Slooten, C.; Peperzak, L. 2013. Microbial dynamics in acetate-enriched ballast water at different temperatures, Ecotoxicology and Environmental Safety 96: 93-98. http://dx.doi.org/10.1016/j.ecoenv.2013.06.027

Šateikienė, D.; Januteniené, J. 2012. Ballast water treatment technologies comparative analysis, in Transport means 2012: Proceedings of the 16th International Conference, 2526 October 2012, Kaunas, Lithuania, 241-244.

Tamburri, M. N.; Wasson, K.; Matsuda, M. 2002. Ballast water deoxygenation can prevent aquatic introductions while reducing ship corrosion, Biological Conservation 103(3): $331-341$. http://dx.doi.org/10.1016/S0006-3207(01)00144-6
Tang, Z.; Butkus, M. A.; Xie, Y. F. 2009. Enhanced performance of crumb rubber filtration for ballast water treatment, Chemosphere 74(10): 1396-1399.

http://dx.doi.org/10.1016/j.chemosphere.2008.11.048

Werschkun, B.; Sommer, Y.; Banerji, S. 2012. Disinfection byproducts in ballast water treatment: an evaluation of regulatory data, Water Research 46(12): 4884-4901. http://dx.doi.org/10.1016/j.watres.2012.05.034

Zhang, N.; Ma, B.; Li, J; Zhang, Z. 2013. Factors affecting formation of chemical by-products during ballast water treatment based on an advanced oxidation process, Chemical Engineering Journal 231: 427-433. http://dx.doi.org/10.1016/j.cej.2013.07.055 